\title{
BENEFIT OF ABCIXIMAB IN PATIENTS WITH REFRACTORY UNSTABLE ANGINA IN RELATION TO SERUM TROPONIN T LEVELS
}

\author{
Christian W. Hamm, M.D., Christopher Heeschen, M.D., Britta Goldmann, M.D., Alec Vahanian, M.D., \\ Jennifer Adgey, M.D., Carlos Macaya Miguel, M.D., Wolfgang Rutsch, M.D., \\ Juergen Berger, Ph.D., Jille Kootstra, and MaArten L. Simoons, M.D., \\ for the c7E3 Fab Antiplatelet Therapy in Unstable Refractory Angina (CAPTURE) Study InVestigators*
}

\begin{abstract}
Background In patients with refractory unstable angina, the platelet glycoprotein IIb/IIla-receptor antibody abciximab reduces the incidence of cardiac events before and during coronary angioplasty. We investigated whether serum troponin T levels identify patients most likely to benefit from therapy with this drug.
\end{abstract}

Methods Among 1265 patients with unstable angina who were enrolled in the c7E3 Fab Antiplatelet Therapy in Unstable Refractory Angina (CAPTURE) trial, serum samples drawn at the time of randomization to abciximab or placebo were available from 890 patients; we used these samples for the determination of troponin T and creatine kinase MB levels. Patients with postinfarction angina were not included.

Results Serum troponin T levels at the time of study entry were elevated (above $0.1 \mathrm{ng}$ per milliliter) in 275 patients (30.9 percent). Among patients receiving placebo, the risk of death or nonfatal myocardial infarction was related to troponin $\mathrm{T}$ levels. The six-month cumulative event rate was 23.9 percent among patients with elevated troponin T levels, as compared with 7.5 percent among patients without elevated troponin $T$ levels $(P<0.001)$. Among patients treated with abciximab, the respective sixmonth event rates were 9.5 percent for patients with elevated troponin $\mathrm{T}$ levels and 9.4 percent for those without elevated levels. As compared with placebo, the relative risk of death or nonfatal myocardial infarction associated with treatment with abciximab in patients with elevated troponin T levels was 0.32 (95 percent confidence interval, 0.14 to $0.62 ; P=0.002$ ). The lower event rates in patients receiving abciximab were attributable to a reduction in the rate of myocardial infarction (odds ratio, 0.23; 95 percent confidence interval, 0.12 to $0.49 ; \mathrm{P}<0.001$ ). In patients without elevated troponin $T$ levels, there was no benefit of treatment with respect to the relative risk of death or myocardial infarction at six months (odds ratio, 1.26; 95 percent confidence interval, 0.74 to $2.31 ; \mathrm{P}=0.47$ ).

Conclusions The serum troponin T level, which is considered to be a surrogate marker for thrombus formation, identifies a high-risk subgroup of patients with refractory unstable angina suitable for coronary angioplasty who will particularly benefit from antiplatelet treatment with abciximab. (N Engl J Med 1999;340:1623-9.)

(C)1999, Massachusetts Medical Society.

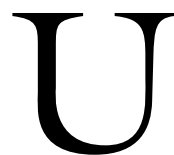

NSTABLE angina is a critical phase of coronary heart disease that is defined by clinical symptoms and is associated with a high risk of myocardial infarction and death. ${ }^{1}$ The underlying pathophysiologic mechanism involves rupture or erosion of atherosclerotic plaques, followed by local thrombus formation. ${ }^{2-4}$ If thrombotic material is transported downstream, focal cell necrosis will result. ${ }^{3}$ Such minor myocardial injury is detected in 20 to 40 percent of patients with unstable angina by the measurement of serum troponin $\mathrm{T}$ or troponin I, but rarely by measurement of serum creatine kinase. ${ }^{5-12}$ Patients with such minor myocardial injury are at increased risk for adverse outcomes - in particular, subsequent myocardial infarction or sudden death. ${ }^{6-15}$

The recent c7E3 Fab Antiplatelet Therapy in Unstable Refractory Angina (CAPTURE) trial demonstrated that treatment with the glycoprotein IIb/IIIa-receptor blocker abciximab reduced the risk of myocardial infarction in patients with refractory unstable angina, both during the 18-to-24-hour period preceding the coronary intervention and during subsequent balloon angioplasty. ${ }^{16}$ Since treatment with abciximab is directed against the formation of platelet aggregates, we postulated that such treatment might be particularly effective in patients with elevated troponin $\mathrm{T}$ levels due to thrombotic microembolization. Accordingly, we assessed the value of troponin $\mathrm{T}$ measurements taken at base line among patients in the CAPTURE study in predicting the therapeutic efficacy of abciximab.

\section{METHODS}

\section{Patients}

The study population of the CAPTURE trial was composed of 1265 patients (345 women and 920 men; mean $[ \pm S D]$ age,

From the Department of Cardiology (C.W.H., C.H., B.G.) and the Institute of Mathematics and Computer Science in Medicine (J.B.), University Hospital Eppendorf, Hamburg, Germany; the Service de Cardiologie, Hôpital Tenon, Paris (A.V.); the Cardiac Department of the Royal Victoria Hospital, Belfast, Northern Ireland (J.A.); Unidad de Hemodinamica, Hospital Universitario San Carlos, Madrid (C.M.M.); the Department of Cardiology, Charité University Hospital, Berlin, Germany (W.R.); and Cardialysis and Erasmus University, Rotterdam, the Netherlands (J.K., M.L.S.). Address reprint requests to Dr. Hamm at Kerckhoff Heart Center, Benekestrasse 2-8, D-61231 Bad Nauheim, Germany, or at christian. hamm@kerckhoff.med.uni-giessen.de.

${ }^{*}$ Other participants in the trial are listed in the Appendix. 
$61 \pm 10$ years) who were recruited from 69 centers in 12 countries between May 1993 and December 1995. All the patients had had recurrent chest pain at rest, with concomitant electrocardiographic changes (ST-segment depression, ST-segment elevation, or abnormal $\mathrm{T}$ waves), and had had one or more episodes of chest pain or electrocardiographic abnormalities, or both, within two hours after the initiation of therapy with intravenous heparin and nitroglycerin. The most recent episode of ischemia had to have occurred within 48 hours before randomization (mean, 8.7 \pm 6.0 ). Exclusion criteria were the occurrence of a recent myocardial infarction, unless serum creatine kinase (CK) enzyme activity had returned to less than two times the upper limit of normal; the need for immediate intervention; and the presence of risk factors for bleeding. All patients had evidence on coronary angiography of substantial coronary artery disease (defined by the presence of one culprit lesion suitable for angioplasty). Study medication was started within 24 hours after angiography, and percutaneous transluminal coronary angioplasty (PTCA) was scheduled to be performed 18 to 24 hours after the start of study medication. Additional electrocardiograms were recorded at enrollment; 6,12 , and 18 hours after enrollment; just before PTCA; 1, 6, and 24 hours after PTCA; at discharge; and whenever patients had recurrent chest pain. Further details have been published elsewhere. ${ }^{16}$

Patients were randomly assigned to receive a bolus injection of $0.25 \mathrm{mg}$ of abciximab (ReoPro, Centocor, Leiden, the Netherlands, and Eli Lilly, Indianapolis) per kilogram of body weight, followed by a continuous infusion at a rate of $10 \mu \mathrm{g}$ per minute, or to receive a matching placebo. Treatment was started within two hours after randomization and continued until one hour after the completion of PTCA.

During hospitalization and the six-month follow-up period, all events were recorded, including death, nonfatal myocardial infarction, repeated PTCA, and coronary bypass surgery. Myocardial infarction was diagnosed during the index hospital stay, which included the angioplasty procedure, when the level of CK activity was more than three times the upper limit of normal in at least two samples or when new, clinically significant $Q$ waves were detected in two or more continuous electrocardiographic leads. Myocardial infarction after discharge was diagnosed on the basis of CK values exceeding two times the upper limit of normal or the detection of new, significant $\mathrm{Q}$ waves in two or more continuous leads. With respect to rates of cardiac events, four time points were considered: the period before PTCA (up to 36 hours after randomization), 72 hours after randomization (including up to 36 hours after PTCA), 30 days after randomization, and 6 months after randomization.

\section{Analytic Techniques}

All serum samples were stored at $-20^{\circ} \mathrm{C}$ or lower and transported to a central laboratory, where they were stored at $-80^{\circ} \mathrm{C}$ until they were analyzed. Quantitative determination of the cardiac markers (troponin $\mathrm{T}$ and creatine kinase $\mathrm{MB}$ fraction [CK-MB]) was performed at the research laboratory of the University of Hamburg by technicians who were unaware of the patients' histories and the assigned treatments.

Serum cardiac troponin $\mathrm{T}$ was measured with a one-step enzyme immunoassay that uses magnetic particles carrying the monoclonal antibody and chemiluminescence (Elecsys 2010, Boehringer Mannheim, Mannheim, Germany). The lower limit of detection in this assay was $0.01 \mathrm{ng}$ per milliliter, and the threshold value for the diagnosis (the diagnostic cutoff point) was $0.10 \mathrm{ng}$ per milliliter. ${ }^{17}$ The interassay coefficient of variation was 6.7 percent at a level of $0.12 \mathrm{ng}$ per milliliter and 4.1 percent at $0.56 \mathrm{ng}$ per milliliter with internal controls.

Serum CK-MB levels were determined in parallel with monoclonal antibodies by the same analyzer. The lower limit of detection in this assay was $0.15 \mathrm{ng}$ per milliliter, and the upper reference (cutoff) level was $5.0 \mathrm{ng}$ per milliliter. The interassay coefficient of variation was 8.4 percent at a level of $8.2 \mathrm{ng}$ per milliliter and 7.2 percent at $14.7 \mathrm{ng}$ per milliliter with internal controls.

\section{Statistical Analysis}

To distinguish among patients who derived different degrees of benefit from treatment with abciximab, an exploratory data analysis was chosen. ${ }^{18}$ Patients with measurable troponin $\mathrm{T}$ levels $(>0.01 \mathrm{ng}$ per milliliter) were grouped into quartiles of approximately 130 patients each. For each of the four time points, a logistic-regression analysis was performed. The treatment was included in the model equation as a binary variable and was coded as 0 (placebo) or 1 (abciximab). For troponin $\mathrm{T}$ values, we used four dichotomous indicator variables to represent the ranges within each quartile $(0.02$ to $0.04 \mathrm{ng}$ per milliliter, 0.05 to 0.12 ng per milliliter, 0.13 to $0.32 \mathrm{ng}$ per milliliter, and $>0.32 \mathrm{ng}$ per milliliter). Patients with troponin $\mathrm{T}$ values at or below $0.01 \mathrm{ng}$ per milliliter served as the reference group.

To assess a possible interaction between troponin $\mathrm{T}$ levels and the therapeutic benefit of abciximab, terms denoting the interaction between troponin $\mathrm{T}$ and treatment were incorporated into the model. The model was fitted with and without the interaction terms. If the introduction of the interaction terms improved the fit of the model, the likelihood-ratio test with four degrees of freedom should have indicated statistical significance. The demonstration of an interaction implied differing degrees of benefit with abciximab at various troponin $\mathrm{T}$ levels.

In addition, the troponin $T$ levels $(>0.1$ vs. $\leqslant 0.1 \mathrm{ng}$ per milliliter), CK-MB levels ( $>5.0$ vs. $\leqslant 5.0 \mathrm{ng}$ per milliliter), and electrocardiographic findings (presence vs. absence) were coded as dichotomous variables. Reverse stepwise logistic-regression analysis was used to identify variables with independent predictive value for the therapeutic benefit of abciximab.

Continuous variables were expressed as means $\pm \mathrm{SD}$, and comparisons between two subgroups were performed with the MannWhitney $\mathrm{U}$ test (two-sided). P values below 0.05 were considered to indicate statistical significance. Comparisons of categorical variables were performed with Fisher's exact test (two-sided). All calculations were performed with SPSS version 7.5 (SPSS, Chicago) or StatXact 3 (Cytel Software, Cambridge, Mass.) software.

\section{RESULTS}

Among 1265 patients enrolled in the CAPTURE trial, 198 patients were excluded from the analysis because they had myocardial infarctions within 14 days before enrollment. Serum troponin $\mathrm{T}$ levels may be elevated for up to 14 days after myocardial infarction, and high values therefore do not necessarily reflect minor myocardial damage in these patients. ${ }^{5}$ The results of the analyses of the serum samples obtained at the time of randomization were available for 890 of the remaining 1067 patients $(83$ percent).

The base-line characteristics of these 890 patients were similar to those of the total study population with respect to age, sex, cardiovascular-risk profile, and concomitant treatment before and after randomization. During the six months of follow-up, 19 deaths were recorded and 79 patients had nonfatal myocardial infarctions. The degree of reduction in the incidence of cardiac events among the $890 \mathrm{pa}$ tients in the current analysis was similar to that in the entire CAPTURE study population before PTCA (event rate, 2.4 percent among those receiving placebo vs. 0.9 percent among those receiving abciximab; $\mathrm{P}=0.12), 72$ hours after randomization $(8.3$ percent vs. 4.3 percent, $\mathrm{P}=0.02)$, and 30 days after randomization (9.4 percent vs. 5.4 percent, $\mathrm{P}=0.012$ ). 
The absolute difference in event rates in the two treatment groups was fairly consistent during the six-month follow-up; at six months this difference was 4.3 percentage points, although it was no longer significant (12.9 percent vs. 8.6 percent, $\mathrm{P}=0.14$ ).

\section{Interaction between Serum Troponin T Level and the Therapeutic Benefit of Abciximab}

To characterize a possible relation between baseline serum troponin T levels and the benefit of treatment with abciximab, the patients were categorized according to troponin $\mathrm{T}$ level (Table $\mathrm{l}$ ). Troponin $\mathrm{T}$ was not detectable in 372 patients (41.8 percent) 182 receiving placebo and 190 receiving abciximab. In these patients, the event rates did not differ significantly between the placebo and abciximab groups during the 36 hours before PTCA ( 0 vs. 0.5 percent, $\mathrm{P}=1.00)$. Although there was a trend toward reduced events during the period up to 72 hours after randomization for the patients receiving abciximab (4.9 percent vs. 2.1 percent, $\mathrm{P}=0.17$ ), this difference was not as apparent at 30 days $(4.9$ percent vs. 2.6 percent, $\mathrm{P}=0.28$ ) or after 6 months of follow-up (6.6 percent vs. 6.3 percent, $\mathrm{P}=1.00)$.

Troponin $\mathrm{T}$ was detectable in base-line serum samples of 518 patients ( 58.2 percent). Patients were stratified into quartiles according to the level of troponin T measured: 0.02 to $0.04 \mathrm{ng}$ per milliliter (138 patients), 0.05 to $0.12 \mathrm{ng}$ per milliliter (129 patients), 0.13 to $0.32 \mathrm{ng}$ per milliliter (123 patients), and $>0.32 \mathrm{ng}$ per milliliter (128 patients). Table 1 shows that in patients with troponin $\mathrm{T}$ levels of $0.12 \mathrm{ng}$ per milliliter or less, event rates were low and did not differ significantly between those receiving abciximab and those receiving placebo at all four time points. In contrast, for patients with troponin $\mathrm{T}$ levels above $0.12 \mathrm{ng}$ per milliliter, the risk of a cardiac event was higher in the placebo group than at lower levels, whereas event rates remained essentially unchanged when patients were treated with abciximab. This interaction between the therapeutic benefit of abciximab and the troponin $\mathrm{T}$ level was statistically significant at 72 hours, 30 days, and 6 months of follow-up. The therapeutic benefit of abciximab in the CAPTURE trial was evident in the two upper quartiles of patients, with troponin $\mathrm{T}$ values higher than 0.12 ng per milliliter (Fig. 1).

\section{Stratification According to Serum Troponin T Level}

Since the therapeutic cutoff level we identified for serum troponin $\mathrm{T}$ is close to the diagnostic cutoff level of $0.1 \mathrm{ng}$ per milliliter, which is widely used in clinical practice, we analyzed the data according to this cutoff level. The base-line characteristics of the 275 patients (30.9 percent) above the cutoff level (those considered to be troponin $\mathrm{T}$-positive) and the 615 patients below this level (those considered to be troponin $\mathrm{T}$-negative) are presented in Table 2 .
Table 1. Cumulative Rates of Cardiac Events According to Troponin T Quartile and Time Point.*

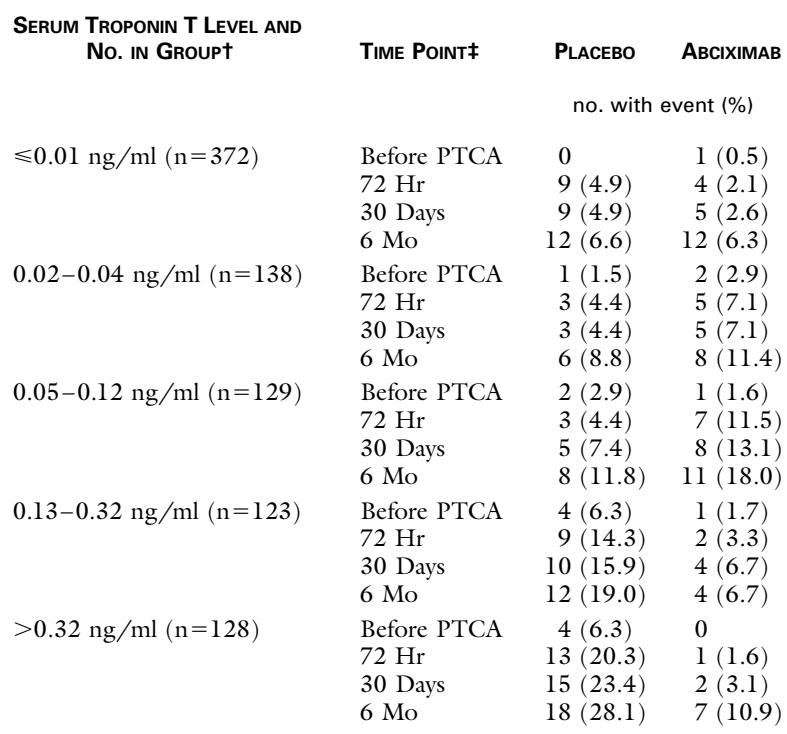

*Events were defined as nonfatal myocardial infarction and death.

†The numbers of patients in each treatment group were as follows: troponin $\mathrm{T}$ level $\leqslant 0.01 \mathrm{ng}$ per milliliter: placebo, 182 ; abciximab, 190 ; troponin $\mathrm{T}$ level 0.02 to $0.04 \mathrm{ng}$ per milliliter: placebo, 68; abciximab, 70 ; troponin T level 0.05 to $0.12 \mathrm{ng}$ per milliliter: placebo, 68; abciximab, 61; troponin $\mathrm{T}$ level 0.13 to $0.32 \mathrm{ng}$ per milliliter: placebo, 63 ; abciximab, 60 ; troponin $\mathrm{T}$ level $>0.32 \mathrm{ng}$ per milliliter: placebo, 64 ; abciximab, 64 .

‡PTCA denotes percutaneous transluminal coronary angioplasty. Except for "before PTCA," times listed are after randomization.

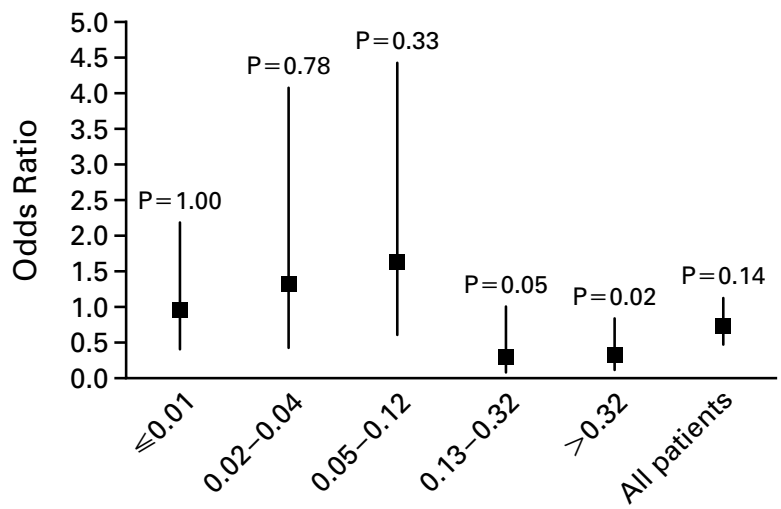

Serum Troponin T (ng/ml)

$\begin{array}{lllllll}\text { No. of } & 372 & 138 & 129 & 123 & 128 & 890\end{array}$

patients

Figure 1. Odds Ratios for Cardiac Events Associated with Treatment with Abciximab at the Six-Month Follow-up, According to Quartile of Serum Troponin T.

Cardiac events were death and nonfatal myocardial infarction. $P$ values are for the comparison with the placebo group. Vertical bars represent 95 percent confidence intervals. 
Table 2. Base-Line Characteristics of the Patients According to Serum Troponin T Level.*

\begin{tabular}{|c|c|c|c|c|}
\hline \multirow[t]{2}{*}{ Characteristic } & \multicolumn{2}{|c|}{ TROPONIN $\mathrm{T}>0.1 \mathrm{ng} / \mathrm{ml}$} & \multicolumn{2}{|c|}{ TROPONIN T $\leqslant 0.1 \mathrm{ng} / \mathrm{ml}$} \\
\hline & $\begin{array}{l}\text { ABCIXIMAB } \\
(\mathrm{N}=136)\end{array}$ & $\begin{array}{l}\text { PLACEBO } \\
(\mathrm{N}=139)\end{array}$ & $\begin{array}{c}\text { ABCIXIMAB } \\
(\mathrm{N}=308)\end{array}$ & $\begin{array}{l}\text { PLACEBO } \\
(\mathrm{N}=307)\end{array}$ \\
\hline Male sex - no. $(\%)$ & $103(75.7)$ & $93(66.9)$ & $216(70.1)$ & $226(73.6)$ \\
\hline Mean $( \pm S D)$ age - yr & $62.4 \pm 10.6$ & $62.7 \pm 10.5$ & $60.1 \pm 9.3$ & $60.9 \pm 10.2$ \\
\hline \multicolumn{5}{|l|}{$\begin{array}{c}\text { History of cardiac disease or } \\
\text { procedures - no. }(\%) \dagger\end{array}$} \\
\hline Angina $>4$ wk previously & $57(41.9)$ & $55(39.6)$ & $166(53.9)$ & $198(64.5)$ \\
\hline $\begin{array}{l}\text { Myocardial infarction } 14-30 \\
\text { days previously }\end{array}$ & $4(2.9)$ & $3(2.2)$ & $13(4.2)$ & $10(3.3)$ \\
\hline $\begin{array}{l}\text { Myocardial infarction }>30 \\
\text { days previously }\end{array}$ & $26(19.1)$ & $22(15.8)$ & $63(20.5)$ & $70(22.8)$ \\
\hline PTCA & $16(11.8)$ & $12(8.6)$ & $49(15.9)$ & $57(18.6)$ \\
\hline CABG & $2(1.5)$ & $5(3.6)$ & $4(1.3)$ & $13(4.2)$ \\
\hline \multicolumn{5}{|l|}{$\begin{array}{l}\text { Medication received before } \\
\text { enrollment - no. }(\%)\end{array}$} \\
\hline Aspirin & $125(91.9)$ & $131(94.2)$ & $266(86.4)$ & $286(93.2)$ \\
\hline Heparin (intravenous) & $134(98.5)$ & $135(97.1)$ & $304(98.7)$ & $306(99.7)$ \\
\hline Nitrates (intravenous) & $136(100.0)$ & $137(98.6)$ & $308(100.0)$ & $307(100.0)$ \\
\hline Beta-blockers & $90(66.2)$ & $87(62.6)$ & $187(60.7)$ & $194(63.2)$ \\
\hline Calcium-channel blockers & $55(40.4)$ & $60(43.2)$ & $149(48.4)$ & $184(59.9)$ \\
\hline \multicolumn{5}{|l|}{$\begin{array}{l}\text { Medication received after } \\
\text { enrollment - no. }(\%)\end{array}$} \\
\hline Aspirin & $132(97.1)$ & $135(97.1)$ & $290(94.2)$ & $299(97.4)$ \\
\hline Ticlopidine & $7(5.1)$ & $5(3.6)$ & $13(4.2)$ & $15(4.9)$ \\
\hline Heparin (intravenous) & $131(96.3)$ & $139(100.0)$ & $295(95.8)$ & $300(97.7)$ \\
\hline Nitrates (intravenous) & $131(96.3)$ & $135(97.1)$ & $291(94.5)$ & $302(98.4)$ \\
\hline Beta-blockers & $91(66.9)$ & $89(64.0)$ & $194(63.0)$ & $186(60.6)$ \\
\hline Calcium-channel blockers & $54(39.7)$ & $60(43.2)$ & $156(50.6)$ & $180(58.6)$ \\
\hline \multicolumn{5}{|l|}{ Risk factors - no. $(\%)$} \\
\hline Diabetes & $18(13.2)$ & $16(11.5)$ & $41(13.3)$ & $29(9.4)$ \\
\hline Hypertension & $48(35.3)$ & $50(36.0)$ & $115(37.3)$ & $114(37.1)$ \\
\hline Current smoking & $56(41.2)$ & $57(41.0)$ & $122(39.6)$ & $128(41.7)$ \\
\hline
\end{tabular}

*Plus-minus values are means \pm SD.

†PTCA denotes percutaneous transluminal coronary angioplasty, and CABG coronary-artery bypass graft.
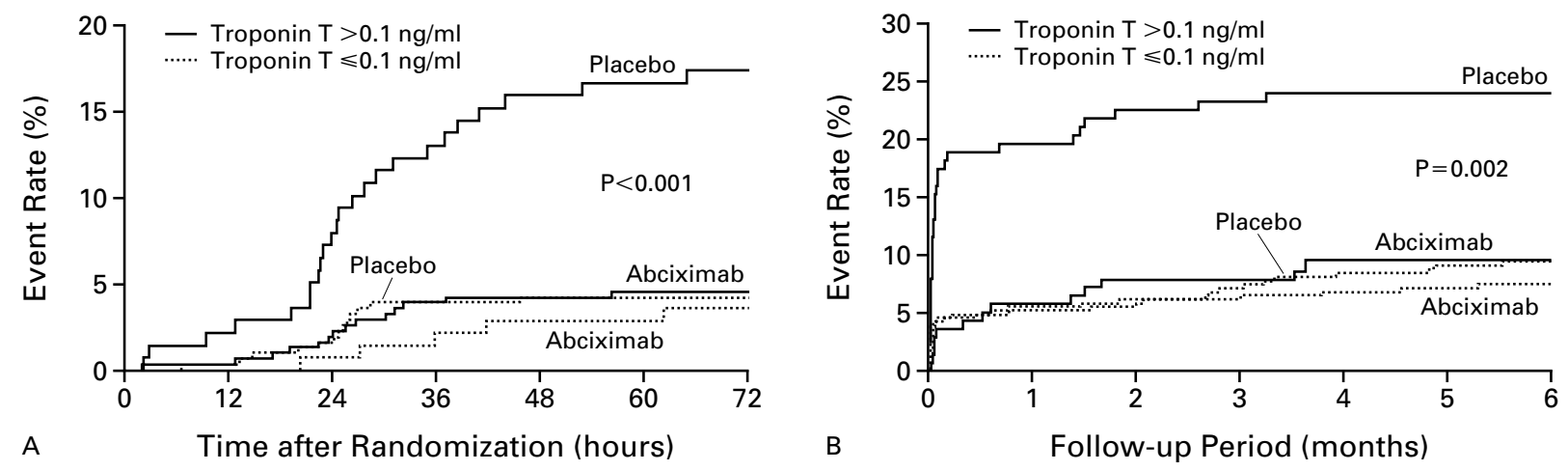

Figure 2. Rates of Cardiac Events in the Initial 72 Hours after Randomization (Panel A) and during the 6 Months of Follow-up (Panel B) among Patients with Serum Troponin T Levels above and Those with Levels below the Diagnostic Cutoff Point.

Cardiac events were death and nonfatal myocardial infarction. Percutaneous transluminal coronary angioplasty was performed 18 to 24 hours after randomization. 
Table 3. Cumulative Rates of Cardiac Events According to Time Point.*

\begin{tabular}{|c|c|c|c|c|c|}
\hline \multirow[t]{3}{*}{$\begin{array}{c}\text { Serum Troponin } \\
\text { T LEVEL }\end{array}$} & \multicolumn{4}{|c|}{ Event Rate } & \multirow[t]{3}{*}{ MORTALITY } \\
\hline & $\begin{array}{l}\text { BEFORE } \\
\text { PTCA }\end{array}$ & $\begin{array}{c}72 \text { HR AFTER } \\
\text { RANDOMIZATION }\end{array}$ & $\begin{array}{l}30 \text { DAYS AFTER } \\
\text { RANDOMIZATION }\end{array}$ & $\begin{array}{c}6 \text { MO AFTER } \\
\text { RANDOMIZATION }\end{array}$ & \\
\hline & \multicolumn{4}{|c|}{ percent } & \\
\hline \multicolumn{6}{|l|}{$\leqslant 0.1 \mathrm{ng} / \mathrm{ml}$} \\
\hline Placebo & 0.7 & 4.2 & 4.9 & 7.5 & 1.3 \\
\hline Abciximab & 1.0 & 4.5 & 5.2 & 9.4 & 1.9 \\
\hline$P$ value & 1.00 & 1.00 & 1.00 & 0.47 & 0.75 \\
\hline \multicolumn{6}{|l|}{$>0.1 \mathrm{ng} / \mathrm{ml}$} \\
\hline Placebo & 6.6 & 17.4 & 19.6 & 23.9 & 3.6 \\
\hline Abciximab & 0.7 & 3.6 & 5.8 & 9.5 & 2.9 \\
\hline$P$ value & 0.02 & 0.007 & 0.001 & 0.002 & 0.74 \\
\hline
\end{tabular}

${ }^{*}$ Events were defined as nonfatal myocardial infarction and death. PTCA denotes percutaneous transluminal coronary angioplasty.

†The mortality rate was for the six-month period after randomization.

There were no significant differences between these groups.

Cardiac events (death or nonfatal myocardial infarction) are shown according to troponin $\mathrm{T}$ level and the randomly assigned treatment group in Figure 2. Among the troponin T-negative patients who were receiving placebo, events during the 36 hours before PTCA were infrequent $(0.7$ percent $)$, whereas events occurred in association with the procedure (within 72 hours after randomization) in 3.5 percent of patients. Only a few additional events were recorded in the subsequent six months of follow-up, resulting in a total event rate of 7.5 percent (odds ratio, 1.26; 95 percent confidence interval, 0.74 to $2.31 ; \mathrm{P}=0.47)$. There were no significant differences in event rates between the placebo and abciximab groups at any of the four time points (Table 3 ).

In contrast, the event rates for troponin $\mathrm{T}$-positive patients who were receiving placebo were high - both before PTCA (6.6 percent) and in association with PTCA (10.8 percent), as well as during the subsequent period after discharge, resulting in a total event rate of 23.9 percent at six months $(\mathrm{P}<0.001$ for comparison with troponin $\mathrm{T}-$ negative patients). The rates of events occurring before and in association with PTCA were reduced by treatment with abciximab - to 0.7 percent before PTCA (odds ratio, 0.45 ; 95 percent confidence interval, 0.21 to $0.95 ; \mathrm{P}=0.02$ ) and to 2.9 percent in the 72 hours after randomization (cumulative event rate, 3.6 percent; odds ratio, 0.29 ; 95 percent confidence interval, 0.11 to $0.54 ; \mathrm{P}=0.007)$. This initial benefit - an absolute risk reduction of 13.8 percentage points at 30 days - was preserved during the six months of follow-up (cumulative event rates, 9.5 percent for the abciximab group vs. 23.9 percent for the placebo group; odds ratio, $0.32 ; 95$ percent confidence interval, 0.14 to $0.62 ; \mathrm{P}=0.002$ ).

The risk of cardiac events among the troponin $\mathrm{T}$-positive patients treated with abciximab was similar to that observed among the troponin $\mathrm{T}$-negative patients (Table 3 ). The lower event rates were attributable to a reduction in the rate of myocardial infarction (odds ratio, $0.23 ; 95$ percent confidence interval, 0.12 to $0.49 ; \mathrm{P}<0.001$ ). Total mortality in the CAPTURE trial was low, 0.8 percent at 30 days and 2.1 percent at 6 months. Among the troponin $\mathrm{T}$-positive patients, mortality in the placebo group was 3.6 percent and did not differ significantly from that in the abciximab group ( 2.9 percent, $\mathrm{P}=0.74)$.

\section{Serum CK-MB Level}

At the time of study entry, the CK-MB value was above the cutoff level of $5.0 \mathrm{ng}$ per milliliter in 116 patients (13.0 percent; 63 receiving placebo and 53 receiving abciximab). The mean value was $8.7 \pm 6.2$ ng per milliliter (range, 5.0 to 36.5 ).

The presence of an elevated CK-MB level was a significant predictor of an increased risk of cardiac events at all time points. However, a regression analysis that included a term for interaction indicated no significant relation between the CK-MB level and the benefit of treatment with abciximab. This lack of relation was consistent regardless of CK-MB level or time point. At the six-month follow-up, there was no significant benefit of abciximab treatment, either among the patients with CK-MB levels above 5.0 ng per milliliter (odds ratio, $0.63 ; 95$ percent confidence interval, 0.28 to $1.24 ; \mathrm{P}=0.11$ ) or among those with normal CK-MB values (odds ratio, $0.75 ; 95$ percent confidence interval, 0.48 to $1.14 ; \mathrm{P}=0.16)$. 


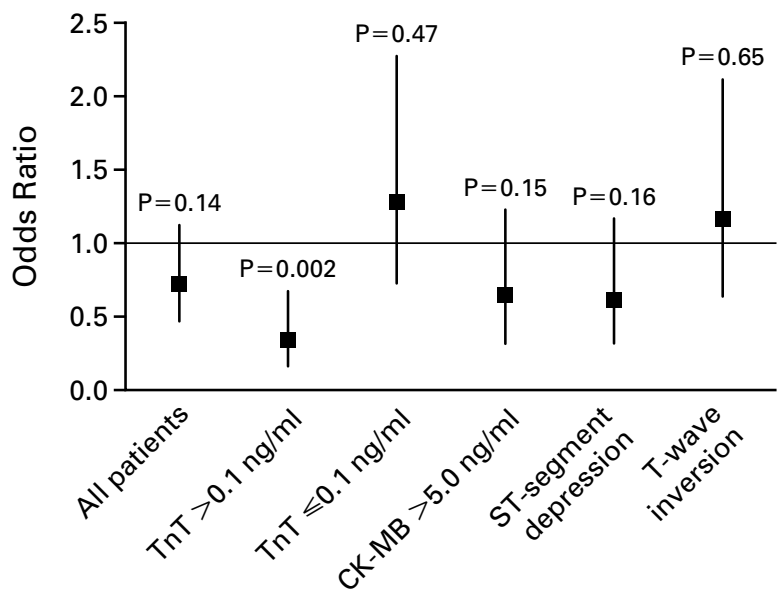

Figure 3. Odds Ratios for Cardiac Events Associated with Treatment with Abciximab at the Six-Month Follow-up, in Subgroups of Patients Defined According to Serum Troponin T (TnT) Level, Serum Creatine Kinase MB Fraction (CK-MB), STSegment Depression, and T-Wave Inversion.

Vertical bars represent 95 percent confidence intervals.

\section{Comparison of Predictive Values}

At six months, only troponin $\mathrm{T}$ levels above the diagnostic cutoff level were significant predictive factors (Fig. 3). In a stepwise logistic-regression model, the inclusion of the CK-MB level and electrocardiographic findings indicating unstable angina (ST-segment depression and T-wave inversion) did not have independent predictive value when troponin $\mathrm{T}$ was forced into the model first.

\section{DISCUSSION}

Previous studies of patients with unstable angina or evolving myocardial infarction without ST-segment elevation have shown that serum troponin $\mathrm{T}$ and troponin I levels are potent, independent predictors of the short-term and long-term risk of myocardial infarction and death. ${ }^{6-15}$ Our findings indicate that patients with refractory unstable angina and elevated troponin $\mathrm{T}$ levels may be treated effectively with glycoprotein IIb/IIIa-receptor blockers.

The CAPTURE trial enrolled patients with refractory unstable angina who were scheduled to undergo PTCA for a single culprit lesion. Treatment with the glycoprotein IIb/IIIa-receptor blocker abciximab effectively reduced the risk of myocardial infarction both before and during PTCA. This post hoc analysis of the serum samples collected on study entry revealed that 30.9 percent of the patients had elevated levels of circulating troponin $\mathrm{T}(>0.1 \mathrm{ng}$ per milliliter), in concordance with other studies. ${ }^{6-15}$ As in previous studies, the level of troponin $\mathrm{T}$ correlated with the event rates.9,11 The six-month event rate in the placebo group was 23.9 percent when troponin $\mathrm{T}$ was elevated, as compared with 7.5 percent when levels were normal $(\mathrm{P}<0.001)$. Abciximab reduced this risk to approximately that of patients with troponin $\mathrm{T}$ levels below the diagnostic cutoff value. The risk reduction brought about by abciximab was mainly apparent as a reduction in the rate of myocardial infarction before as well as during PTCA and was maintained over a period of six months (odds ratio, $0.32 ; \mathrm{P}=0.002$ ). The $\mathrm{CK}-\mathrm{MB}$ level was not predictive of the therapeutic benefit of abciximab.

These findings may serve as the basis for a new therapeutic approach to the treatment of high-risk patients with unstable angina pectoris. High serum levels of troponin $\mathrm{T}$ or troponin $\mathrm{I}$ in such patients reflect an active thrombotic process, with distal embolization of platelet thrombi originating from the culprit lesion. ${ }^{2,3}$ Antithrombotic therapy with high doses of glycoprotein IIb/IIIa-receptor blockers will reduce the incidence of thrombus formation at the culprit lesion and may facilitate the resolution of distal microthrombi. Thus, glycoprotein IIb/IIIareceptor blockers provide protection from further myocardial damage. Our data indicate that this mechanism applies to both thrombotic complications arising from spontaneous plaque disruption (as shown by the reduction of events before PTCA) and thrombotic complications associated with the rupture of plaque induced by PTCA.

The event rate before PTCA and that associated with PTCA were low among the patients with refractory unstable angina who did not have elevated troponin $\mathrm{T}$ levels and who were receiving placebo. In contrast, those with troponin $\mathrm{T}$ levels above 0.1 ng per milliliter had high rates of events before PTCA as well as after the procedure; these rates were effectively reduced by treatment with abciximab. Treatment of 100 patients with elevated troponin $\mathrm{T}$ levels with abciximab, rather than standard treatment, would prevent 15 cardiac events. Similarly, in the Fragmin during Instability in Coronary Artery Disease trial, the benefit of prolonged treatment with low-molecular-weight heparin was apparent only in patients with elevated troponin T levels, and only over a period of 42 days. ${ }^{19}$ However, the rates of cardiac events and coronary interventions in that trial were lower than in the CAPTURE trial.

There are a few limitations to using troponin $\mathrm{T}$ measurements in therapeutic decision making. The timing of sampling is crucial for accurate interpretation of troponin $\mathrm{T}$ findings. Measuring troponin $\mathrm{T}$ a mean of 8.7 hours after the qualifying episode of chest pain, as was done in this study, appears adequate, whereas a single measurement obtained on arrival at the hospital was shown to be inappropriate for determining risk. ${ }^{10}$ The absence of detectable troponin $\mathrm{T}$ does not rule out the presence of coronary heart disease, but it does identify a patient at 
lower risk for cardiac events. Positive tests for troponin $\mathrm{T}$ can also indicate other serious conditions, such as acute pulmonary embolism or myocarditis, ${ }^{10}$ but false positive tests are rare..$^{20}$

In conclusion, troponin $\mathrm{T}$ may serve as a surrogate marker of active thrombus formation. An elevated troponin $\mathrm{T}$ value $(>0.1$ ng per milliliter) identifies some patients with unstable angina who are at high risk for cardiac events both before and after PTCA and who will benefit the most from treatment with abciximab. Accordingly, this study demonstrates how a new diagnostic test (for detecting troponin $\mathrm{T}$ ) and a therapeutic advance (abciximab) can be combined for the benefit of patients with acute coronary syndromes.

Presented in part at the 47th Annual Scientific Session of the American College of Cardiology, Atlanta, March 29-April 1, 1998.

We are indebted to Sabine Woblrath and Ariane Deu for their expert technical assistance.

\section{APPENDIX}

In addition to the authors, the following persons participated in the CAPTURE trial: the Netherlands - M. de Boer, H. Suryapranata, A. Liem, and G. Velsink, Zwolle; G. Laarman, R. van der Wieken, J. Ezechiels, and S. Zonneveld, Amsterdam; M. van den Brand, C. van der Zwaan, and P. Kint, Rotterdam; R. Michels, J. Bonnier, I. van de Kerkhof, and C. Hanekamp, Eindhoven; J. Peels, L. Drok, and P. den Heijer, Groningen; T. Plokker, E. Mast, and K. Marquez, Nieuwegein; A. Van den Bos and U. Chin, Breda; V. Umans, J. Cornel, and A. Arnold, Alkmaar; France - E. Gabarz, O. Nallet, and B. Farrah, Paris; D. Carrie, J. Puel, and M. Jean, Toulouse; B. Charbonnier, G. Pacouret, and R. Raynaud, Tours; B. Bertrand and G. Vanzetto, Grenoble; G. Grollier and B. Valette, Caen; C. Thery and J. Lablanche, Lille; F. Duclos and P. Coste, Pessac; P. Beaufils and E. Eiferman, Paris; C. Daubert and C. Leclercq, Rennes; J. Juliard and P. Steg, Paris; J. Bassand and N. Meneveau, Besançon; J. Guermonprez, Paris; Belgium - M. Vrolix, J. Van Lierde, and S. Jacobs, Genk; J. Boland, G. Saat, and P. Baumans, Liege; G. Heyndricks, F. Staelens, and B. De Bruyne, Aalst; Y. Taeymans and P. Gheeraert, Ghent; J. Col and K. alSchwafi, Brussels; P. van den Heuvel and R. Rogiers, Antwerp; M. Castadot and E. de Wit, Brussels; Germany - D. Gulba, R. Dechend, and S. Christow, Berlin-Buch; R. Simon and N. Al Mokthari, Kiel; J. vom Dahl and U. Janssens, Aachen; M. Haude and D. Baumgart, Essen; K. Karsch and R. Maier, Tübingen; C. Brunckhorst, Berlin; N. Reifart and M. Krajcar, Frankfurt; H. Rupprecht and M. Cobaugh, Mainz; Spain-R. Hernandez-Antolin, J. Segovia, and P. Garcia, Madrid; A. Cequir, E. Esplugas, J. Gomez-Hospital, and J. Mauri, Bellvitge; J. Angel and R. Ballester, Barcelona; C. Morris de la Tassa and F. Barriales, Oviedo; J. Auge and J. Garcia, Barcelona; R. Melgares, Granada; United Kingdom - M. Khan, P. Johnston, and Y. McKay, Belfast; M. Been and A. Kahn, Coventry; C. Ilsley and A. Ewan, Harefield; D. Reid and A. McDermott, Newcastle; D. Ward, London; N. Buller, London; R. Balcon, London; Italy - C. Vassanello, P. Zardini, and I. Loschiavo, Verona; A. Casari, A. Piti, and A. Costalunga, Bergamo; S. Repetto and S. Carella, Varese; M. Marzilli and S. Fedele, Pisa; R. Chioiin and B. Reimers, Padua; A. Mazzari, Gemelli; G. Specchia, Pavia; M. Chiariello, Naples; Israel - H. Miller and D. Shepps, Tel Aviv; S. Sclarovski and B. Gal, Tel Aviv; A. Caspi and O. Ayzenberg, Rehovot; T. Sharir and H. Hod, Tel Aviv; Switzerland - P. Buser, M. Pfisterer, and R. Ritz, Basel; O. Bertel and F. Rohner, Zurich; Canada - J.
Ducas and U. Shick, Winnipeg, Man.; P. Cheung, Winnipeg, Man; R. Chisholm, Toronto; A. Adelman, Toronto; E. Cohen, Toronto; PortugalR. Seabra Gomez and J. Ferreira, Lisbon; Austria - V. Mühlberger, Innsbruck.

\section{REFERENCES}

1. Braunwald E. Unstable angina: a classification. Circulation $1989 ; 80$ : 410-4.

2. Davies MJ, Thomas AC, Knapman PA, Hangartner JR. Intramyocardial platelet aggregation in patients with unstable angina suffering sudden ischemic cardiac death. Circulation 1986;73:418-27.

3. Falk E. Unstable angina with fatal outcome: dynamic coronary thrombosis leading to infarction and/or sudden death: autopsy evidence of recurrent mural thrombosis with peripheral embolization culminating in total vascular occlusion. Circulation 1985;71:699-708.

4. Farb A, Burke AP, Tang AL, et al. Coronary plaque erosion without rupture into a lipid core: a frequent cause of coronary thrombosis in sudden coronary death. Circulation 1996;93:1354-63.

5. Gerhardt W, Katus H, Ravkilde J, et al. S-troponin T in suspected ischemic myocardial injury compared with mass and catalytic concentrations of S-creatine kinase isoenzyme MB. Clin Chem 1991;37:1405-11.

6. Hamm CW, Ravkilde J, Gerhardt W, et al. The prognostic value of se rum troponin $\mathrm{T}$ in unstable angina. $\mathrm{N}$ Engl J Med 1992;327:146-50.

7. Ravkilde J, Horder M, Gerhardt W, et al. Diagnostic performance and prognostic value of serum troponin $\mathrm{T}$ in suspected acute myocardial infarction. Scand J Clin Lab Invest 1993;53:677-85.

8. Ravkilde $J$, Nissen $H$, Horder $M$, Thygesen K. Independent prognostic value of serum creatine kinase isoenzyme MB mass, cardiac troponin $\mathrm{T}$ and myosin light chain levels in suspected acute myocardial infarction: analysis of 28 months of follow-up in 196 patients. J Am Coll Cardiol 1995;25: 574-81

9. Lindahl B, Venge $\mathrm{P}$, Wallentin L. Relation between troponin $\mathrm{T}$ and the risk of subsequent cardiac events in unstable coronary artery disease. Circulation 1996;93:1651-7.

10. Hamm CW, Goldmann BU, Heeschen C, Kreymann G, Berger J Meinertz T. Emergency room triage of patients with acute chest pain by means of rapid testing for cardiac troponin T or troponin I. N Engl J Med 1997:337:1648-53.

11. Antman EM, Tanasijevic MJ, Thompson B, et al. Cardiac-specific troponin I levels to predict the risk of mortality in patients with acute coronary syndromes. N Engl J Med 1996;335:1342-9.

12. Luscher MS, Thygesen K, Ravkilde J, Heickendorff L, TRIM Study Group. Applicability of cardiac troponin T and I for early risk stratification in unstable coronary artery disease. Circulation 1997;96:2578-85.

13. Stubbs P, Collinson P, Moseley D, Greenwood T, Noble M. Prognostic significance of admission troponin $\mathrm{T}$ concentrations in patients with myocardial infarction. Circulation 1996;94:1291-7.

14. Wu AH, Abbas SA, Green $S$, et al. Prognostic value of cardiac troponin $\mathrm{T}$ in unstable angina pectoris. Am J Cardiol 1995;76:970-2.

15. Ohman EM, Armstrong PW, Christenson RH, et al. Cardiac troponin $\mathrm{T}$ levels for risk stratification in acute myocardial ischemia. N Engl J Med 1996;335:1333-41.

16. The CAPTURE Investigators. Randomised placebo-controlled trial of abciximab before and during coronary intervention in refractory unstable angina: the CAPTURE Study. Lancet 1997;349:1429-35. [Erratum, Lancet 1997;350:744.]

17. Mueller-Bardorff $M$, Hallermayer $K$, Schroder A, et al. Improved troponin T ELISA specific for cardiac troponin T isoform: assay development and analytical and clinical validation. Clin Chem 1997;43:458-66.

18. Tukey JW. Exploratory data analysis. Reading, Mass.: Addison-Wesley, 1977.

19. Lindahl B, Venge $P$, Wallentin $L$. Troponin $T$ identifies patients with unstable coronary artery disease who benefit from long-term antithrombotic protection. J Am Coll Cardiol 1997;29:43-8.

20. Bhayana V, Gougoulias T, Cohoe $S$, Henderson AR. Discordance be tween results for serum troponin $\mathrm{T}$ and troponin $\mathrm{I}$ in renal disease. Clin Chem 1995;41:312-7. 